\title{
Impact of climate warming on Arctic benthic biodiversity: a case study of two Arctic glacial bays
}

\author{
Maria Wlodarska-Kowalczuk*, Jan M. Weslawski \\ Institute of Oceanology, Polish Academy of Sciences, Powstanców Warszawy 55, Sopot 81-712, Poland
}

\begin{abstract}
The retreat of Arctic glaciers and a resultant increase in inorganic sedimentation is one of the predicted consequences of global warming. In order to evaluate possible effects of these processes on arctic benthic biodiversity, the fauna of 2 glacial bays, which may be treated as representing the expected phases of the global warming scenario, have been studied. Based on surface water temperature, type of glacier and resulting inorganic sedimentation rates, 'Tikhaia Bay' off Franz Josef Land was chosen to represent an Arctic bay before warming and 'Skoddebukta', off west Spitsbergen, to represent a similar bay already affected by the predicted climate changes. Macrofauna was collected at 35 stations in Skoddebukta and 44 stations in Tikhaia Bay. Different methods of measuring faunal diversity (number of species, Shannon diversity index, k-dominance plots) were applied to data sets representing the similar habitats sampled in both bays; these showed the fauna of Tikhaia Bay to be more diverse than that in Skoddebukta. This finding is explained by the lower level of disturbance due to inorganic sedimentation and by better trophic conditions in the former location, both of which are linked to the level of glacial activity. This case study leads to the conclusion that one of the consequences of climate warming for Arctic ecosystems will be a decline of benthic biodiversity due to an increase in mineral sedimentation from meltwaters.
\end{abstract}

KEY WORDS: Biodiversity $\cdot$ Arctic $\cdot$ Macrozoobenthos

\section{INTRODUCTION}

One of the predicted consequences and signs of climate warming is the retreat of glaciers, which is currently being observed in the Arctic. The Spitsbergen tidal glaciers, for instance, are retreating at a rate of up to $0.5 \mathrm{~km} \mathrm{yr}^{-1}$ (Kongsbreen glacier, Lefauconnier et al. 1994). Similar processes are taking place in the Antarctic-Vaughan \& Doake (1996) reported the dramatic retreat of the most northerly iceshelves on the Antarctic Peninsula, which they linked to the atmospheric warming observed for the last $50 \mathrm{yr}$. A glacial retreat is accompanied by an increase in meltwater outflow and a flux of inorganic particles that is reflected in the deposits of fine-grained glaciomarine

*E-mail: maria@iopan.gda.pl sediments (Svendsen et al. 1996). Syvitski \& Andrews (1994) have attempted to evaluate the changes in fluvial sediment inflow in the Canadian Arctic, applying numerical models to 2 different climate change scenarios involving a warming effect. In both cases they predicted a significant increase in sediment flux over the next 200 yr.

Possible changes of marine biocenoses which may follow climate-driven deglaciation can be predicted by comparing present environments which might be treated as representing different stages of this process. The present study focuses on 2 Arctic glacial bays in which the main differences are water temperature and the type of glacier (i.e. actively retreating 'warm' glacier and a much less active 'cold' type). The study aims to establish whether there is a difference in benthic faunal diversity between the studied bays and how it can be linked to the environmental differences. The 


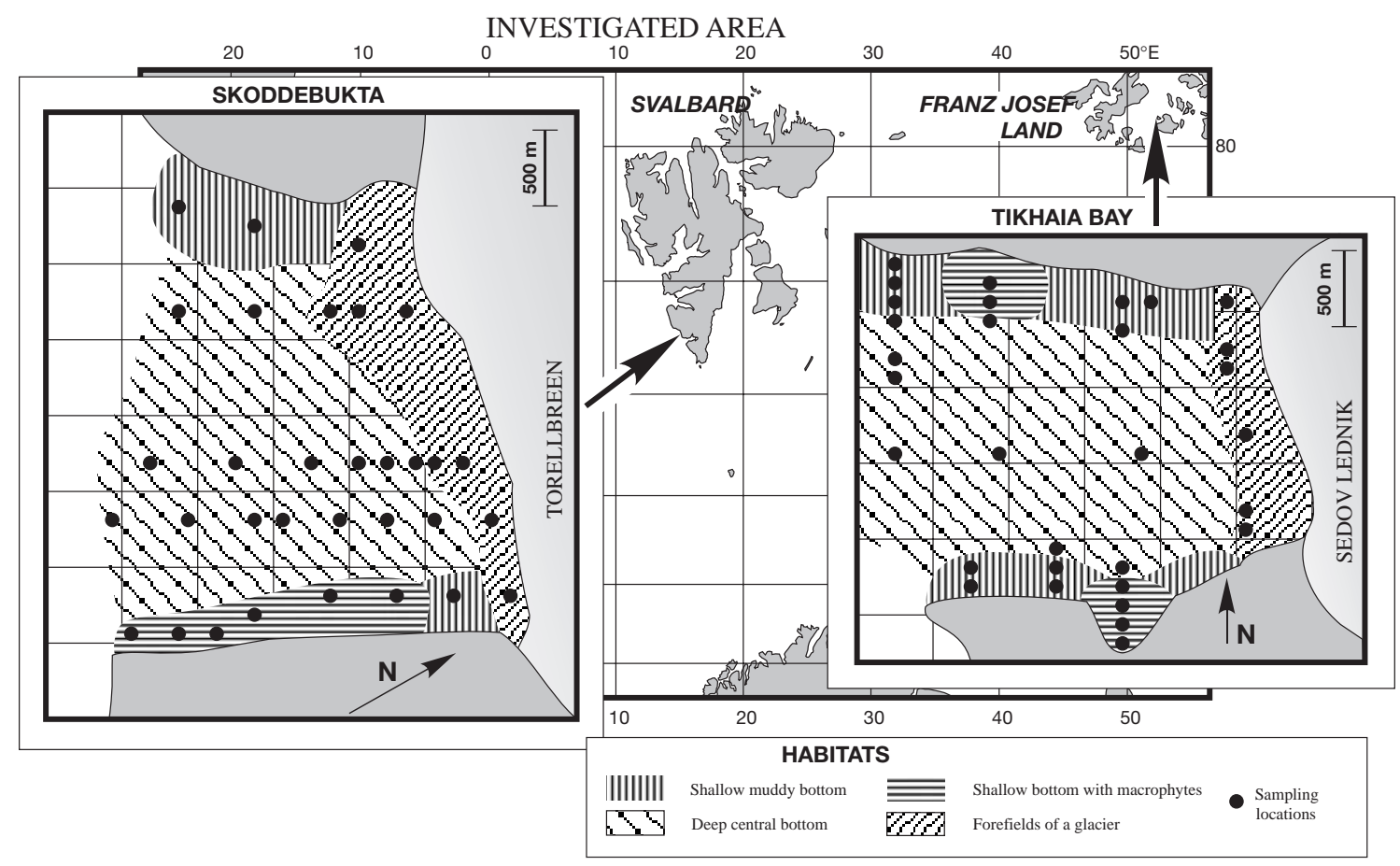

Fig. 1. Study area and location of sampling stations in different habitats. Two arrows on map in background are shown as enlarged areas in foreground

results can be used to predict one of the possible consequences of the climate warming to the arctic ecosystem.

\section{MATERIAL AND METHODS}

Macrofauna was sampled in July 1980 in Skoddebukta, on the western coast of Spitsbergen, and in August-September 1991 and August 1992 in Tikhaia Bay on Hooker Island, Franz Josef Archipelago (Fig. 1). The material was collected using a rectangular dredge $(80 \times 30 \mathrm{~cm})$ in Skoddebukta and a triangle dredge $(30 \times 30 \times 30 \mathrm{~cm})$ in Tikhaia Bay. In both cases a mesh size of $1 \mathrm{~mm}$ was used, and the samples were additionally sieved on a $1 \mathrm{~mm}$ mesh. The material was preserved in $4 \%$ formaldehyde solution.

The sampling sites were selected to cover the whole area of the bays and to get representative material from different habitats. The number and depths of samples taken in different habitats (as described by the bottom type, depth and the distance from the glacier front) in both bays are presented in Table 1. The muddy bottom at the forefields of the glaciers was classified as the habitat representing the bottom covered by the glacier up to 1960 in Skoddebukta and up to 1957 in Tikhaia Bay.

In the laboratory the animals were taxonomically identified and counted. The diversity was described by the number of species per sample, the ShannonWiener index, and k-dominance plots. Natural logarithms were used for Shannon-Wiener index calculations (Shannon \& Weaver 1963). The k-dominance curves were obtained by plotting percentage cumulative abundance against species rank (Lambshead et al. 1983). The analyses were performed using the PRIMER programs package developed at the Plymouth Marine Laboratory, UK.

Table 1. Number (depth range) of samples collected in different habitats

\begin{tabular}{|lrr|}
\hline & Skoddebukta & Tikhaia Bay \\
\hline Muddy bottom in the forefields of the glacier & $7(8-55 \mathrm{~m})$ & $11(5-35 \mathrm{~m})$ \\
Shallow bottom covered with macrophytes & $5(6-10 \mathrm{~m})$ & $8(5-15 \mathrm{~m})$ \\
Shallow muddy bottom & $3(2-3 \mathrm{~m})$ & $11(5-20 \mathrm{~m})$ \\
Deep central bottom, muddy and sandy-muddy sediments & $14(19-60 \mathrm{~m})$ & $14(25-100 \mathrm{~m})$ \\
\hline
\end{tabular}




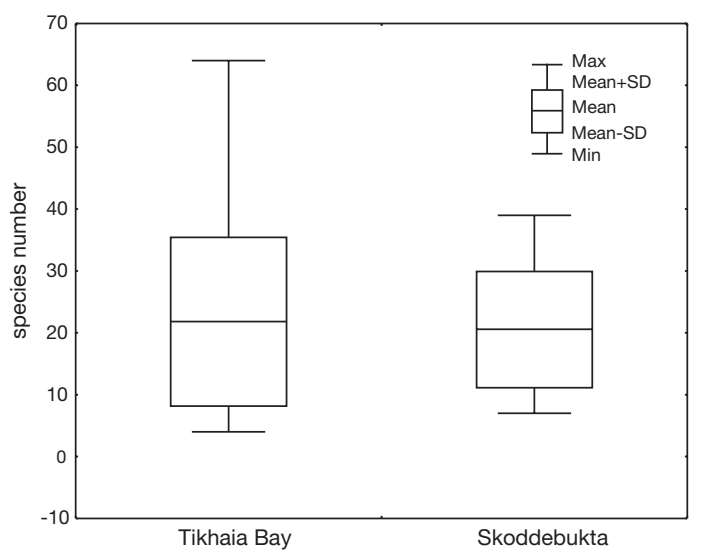

Fig. 2. Number of species per sample in the bays studied

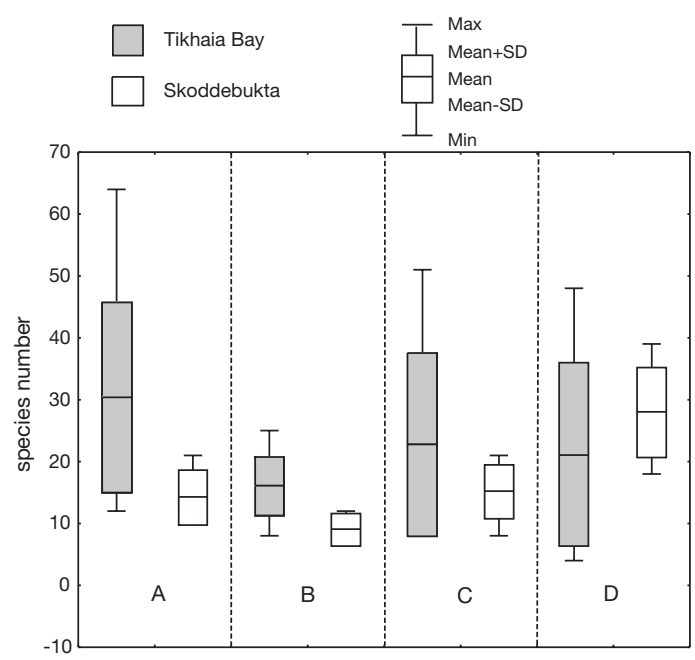

Fig. 3. Number of species per sample in the habitats studied: (A) shallow bottom with macrophytes; (B) shallow muddy bottom; (C) forefields of a glacier; (D) deep central bottom

\section{RESULTS}

107 species were identified in Skoddebukta, 174 in Tikhaia Bay. The list of species is not presented here, as they were reported in Weslawski \& Zajaczkowski (1992) and Wlodarska et al. (1996). The faunal diversity analyses were performed on a set of all samples taken in the studied bays and on subsets of samples taken in 4 habitats (Table 1).

The number of species per sample ranged from 5 to 64 in Tikhaia Bay and from 7 to 39 in Skoddebukta (Fig. 2). The mean values observed for all samples collected in the bays were 22.2 and 19.7 respectively. Mean values calculated for different habitats were higher in Tikhaia Bay than in Skoddebukta, except for the central deep bottom where in Skoddebukta it was 27.9 while in Tikhaia Bay it was 22.1 (Fig. 3).

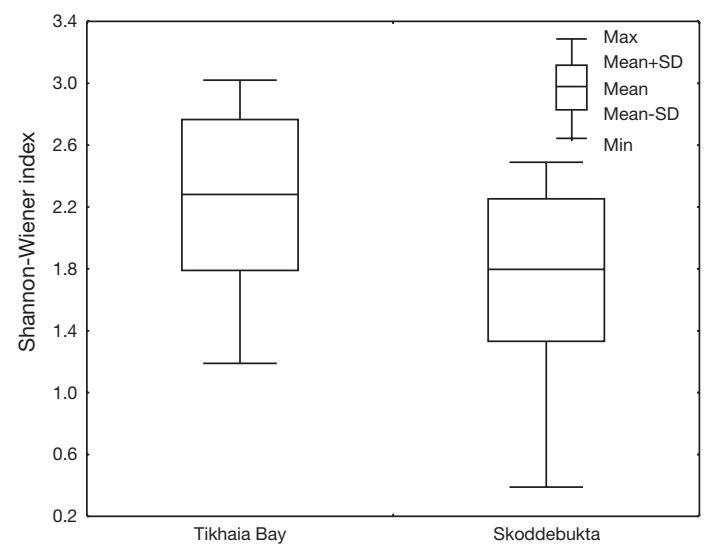

Fig. 4. Shannon-Wiener index values in the bays studied

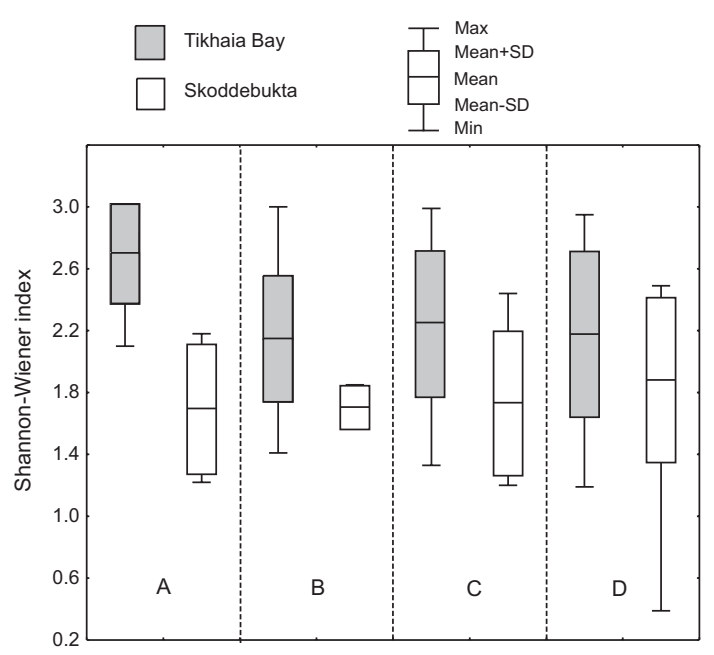

Fig. 5. Shannon-Wiener index values in the habitats studied A, B, C, D as for Fig. 3

Shannon-Wiener diversity indices varied from 0.39 to 2.49 in Skoddebukta and from 1.33 to 3.02 in Tikhaia Bay (Fig. 4). The mean values for all samples collected were 1.84 (Skoddebukta) and 2.3 (Tikhaia Bay). Mean values were higher in Tikhaia Bay in all habitats studied and the difference was the most distinct in case of samples from the shallow bottom covered with macrophytes (Fig. 5).

Fig. 6 presents k-dominance curves for all samples from the bays studied, as well as for all samples from the different habitats. As the curves do not intersect, the data sets are comparable in terms of intristic diversity (Lambshead at al. 1983). In all cases the curve representing fauna from Skoddebukta always lies above the curve representing fauna from Tikhaia Bay, indicating that the fauna of Tikhaia Bay was more diverse in all habitats examined. 

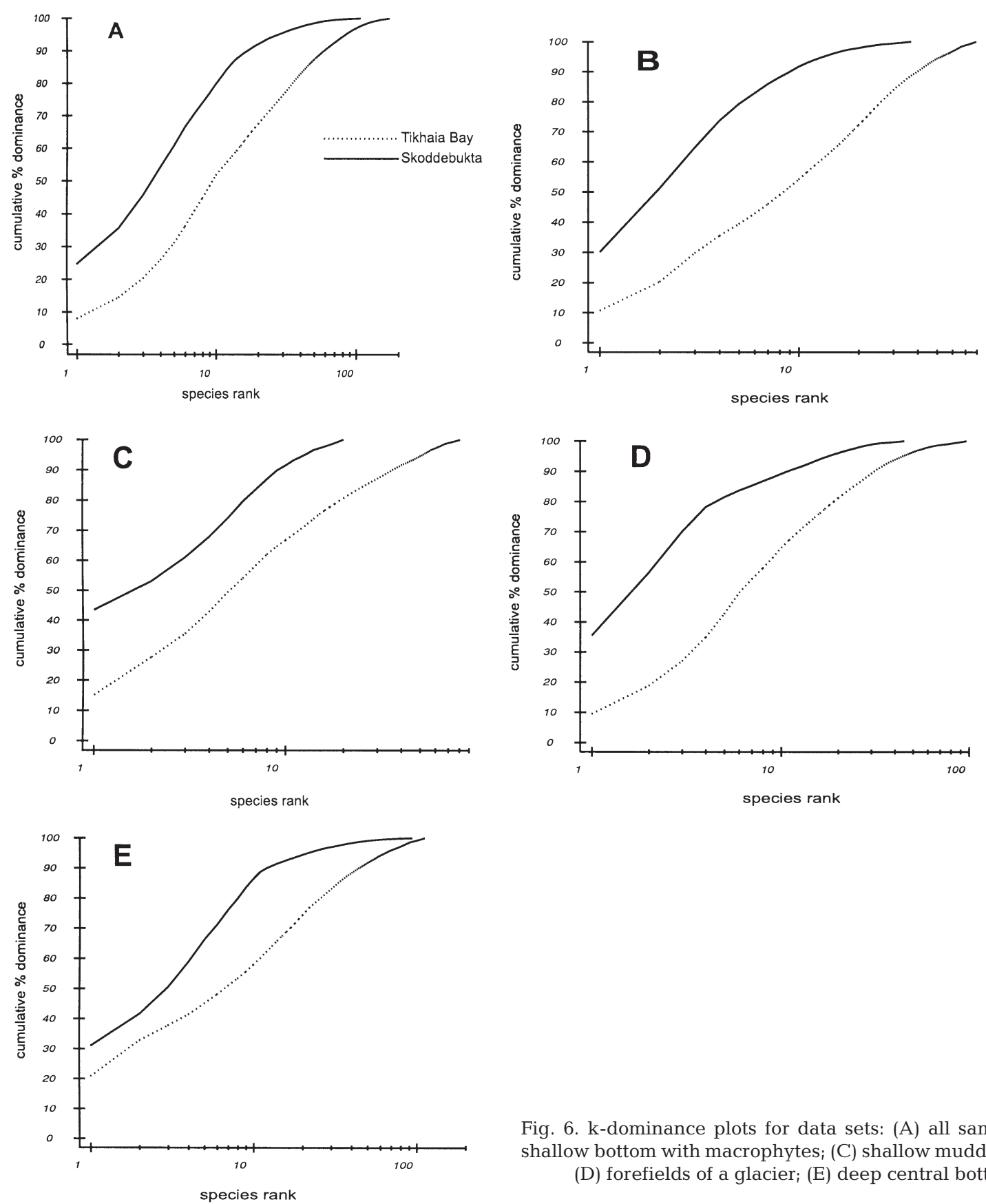

Fig. 6. k-dominance plots for data sets: (A) all samples; (B) shallow bottom with macrophytes; $(C)$ shallow muddy bottom; (D) forefields of a glacier; (E) deep central bottom

\section{DISCUSSION}

The bays studied are similar regarding their geographical position in the Arctic, their overall size $(\sim 2.5 \times 3 \mathrm{~km})$ and geomorphology, the presence of a glacier (of 2 and $3 \mathrm{~km}$ glacier front length), sediment composition (mostly mud and sand-mud) and the salinity of bottom waters (around 34 PSU) Weslawski (1993a). The main differences are: surface water temperature and the activity of the glacier. That is why the bays can be regarded as representative of situations in

different phases of a climate warming scenario: Tikhaia Bay of an Arctic bay before warming and Skoddebukta of a similar bay already affected by the climate changes. The summer surface water temperature in Skoddebukta ranges from 4 to $6^{\circ} \mathrm{C}$ then decreases to $1^{\circ} \mathrm{C}$ in bottom layers, forming a welldefined pycnocline at depths of 20 to $25 \mathrm{~m}$ (own unpubl. data). In Tikhaia Bay the water column temperature ranges from -0.7 to $-1^{\circ} \mathrm{C}$ with a very weak vertical gradient (Swerpel 1992). Torellbreen is a 'warm' active glacier typical of west Spitsbergen 
(Baranowski 1977), while Sedov Lednik is an example of a 'cold' type of glacier (Barr 1995), less active, calving during less than 1 mo in a year (Weslawski 1993a). That results in differences in the amount of glacial melt water and discharge of inorganic suspension to the bays, which is reflected in different levels of water transparency: Secchi depth was 2 to $13 \mathrm{~m}$ in Frantz Josef Land and 0.5 to $2 \mathrm{~m}$ in Svalbard glacier bays (Weslawski \& Stempniewicz 1995). The large amounts of inorganic particles affect the light regimes and hence the primary production in Skoddebukta. Compared with Svalbard waters, Tikhaia Bay experiences a prolonged bloom (Wiktor \& Zajaczkowski 1992), and higher amounts of organic particles can more rapidly reach the bottom due to weak stratification of the water column and hence easier sedimentation in Tikhaia Bay.

In general, the diversity comparisons require the use of strictly standardised methods of sampling and sample-processing; moreover, only similar habitats should be compared (Sanders 1968, Warwick \& Ruswahyuni 1987). Therefore differences in sampling methodology, especially in sampling gear and the mesh size of the sieve, made most of the investigations carried out in Svalbard and neighbouring arctic sites incomparable in terms of faunal diversity (Kendall 1994). In the present study, 4 different habitats were chosen to provide for comparability of data between both bays (in pairs of data from the same habitat, within-habitat diversity) and to present the material representative of the entire benthic fauna of a typical arctic glacial bay. The diversity measures applied have indicated the Tikhaia Bay macrofauna to be more diverse then the Skoddebukta one. That difference has been shown both for within habitats comparisons of pairs of data from the 4 studied habitats and for the data sets comprising all the samples taken in a bay. We assume that the main factor responsible for these differences is that the higher intensity of inorganic sedimentation induced disturbances in Skoddebukta.

Disturbance defined as 'an external force which causes quantifiable deleterious changes to the organisms in an environment' is regarded as an important factor influencing the diversity of marine soft-bottom communities (Lake 1990). Connell (1978) proposed the 'Intermediate Disturbance Hypothesis', which has been incorporated in Huston's (1979) general 'Dynamic Equilibrium Model'. Huston (1979) stated that high diversity is associated with significant frequency or magnitude of disturbance and low population growth rates. However, he assumed that disturbance reduces the populations in density- and species-independent ways and so affects all the populations in a community in the same way. He agreed that under extreme conditions the variability of responses of differ- ent species populations will increase and the diversity will be reduced. That is the case for communities experiencing high levels of inorganic sedimentation, which does not affect all species in the same way. Large amounts of inorganic suspension are especially stressful to suspension feeding and sedentary organisms, as they may clog the filtering organs and hinder their settlement; they can also inhibit reproduction in some species (Wilber 1971, Moore 1977). The low macrofaunal diversity in a number of arctic localities has been attributed to disturbances connected with high inorganic sedimentation induced by glacial or fluvial outflow (Feder \& Jewett 1986, Kendall \& Aschan 1993, Schmid \& Piepenburg 1993, Holte et al. 1996), which has also occurred in other regions (Smith \& Kukert 1996). The higher and more available primary production in Tikhaia Bay must enhance the effect of disturbances induced by inorganic sedimentation and hence enlarge the difference in diversity between the bays studied. Gorlich et al. (1987) indicated that the availability of food may be a limiting factor in high sedimentation areas as organic matter is quickly diluted in large amounts of sedimenting inorganic material. Moreover, animals have to spend much of their energy on the regulatory processes connected with the maintenance of their position in highly unstable substrate, i.e. muddy sediment continuously buried by the rain of inorganic particles. Higher diversity has been attributed to higher levels of primary production and environmental stability by Connell \& Orias (1964). Primary production in arctic waters is generally low compared to temperate and tropical waters (Subba Rao \& Platt 1984 ) and the food supply regulates the benthic biomass, but is also one of the factors influencing the benthic faunal diversity in Arctic food-limited systems (Grebmeier et al. 1988, 1989).

The most obvious direct consequence of atmospheric warming is the rise of coastal water temperatures. The possible magnitude of such a change is still being discussed. One of the models predicts upper ocean temperature to increase by 2 to $4^{\circ} \mathrm{C}$ in $25 \mathrm{yr}$ if atmospheric $\mathrm{CO}_{2}$ concentration doubles (Bernal 1991). Gray (1997) included this phenomenon as a possible threat to marine diversity, following observations of severe damage in corals caused by an increase in water temperature by $2^{\circ} \mathrm{C}$ in the Caribbean. In our opinion, such an increase in water temperature will have a much less pronounced effect on Arctic macrofaunal diversity. Most of the species observed in Arctic waters thrive at a relatively wide range of temperatures, as has been shown for key species on Spitsbergen (Weslawski 1993b) and this is connected with the low level of endemism of Arctic fauna. However, rising temperatures may induce a geographical shift of species and resultant changes in biodiversity may occur. Our 
results suggest that a significant decline in macrobenthic diversity will follow the increase in the amount of inorganic material in coastal waters, which is one of the predicted consequences of climate warming in polar regions. The magnitude of these processes will obviously stem from the magnitude of climate and associated cryosphere changes, while their geographical range will probably be restricted to waters in the immediate vicinity of glaciers. However, the effects may not be negligible, as in West Spitsbergen, for example, glacier-influenced bays occupy $30 \%$ of coastal waters (Weslawski et al. 1995).

\section{LITERATURE CITED}

Baranowski S (1977) Subpolar glaciers of Spitsbergen against the climate of the region. Acta Univ Vrat Stud Geogr 393: $1-157$

Barr S (1995) Franz Josef Land. Polarhandbok nr 8, Norsk Polarinstitutt, Oslo

Bernal PA (1991) Consequences of global change for oceans: a review. Clim Change 18:339-359

Connell JH (1978) Diversity in tropical rain forests and coral reefs. Science 199:1302-1310

Connell JH, Orias E (1964) The ecological regulation of species diversity. Am Nat 98:399-414

Feder HM, Jewett SC (1986) The subtidal benthos. In: Hood DW, Zimmerman T (eds) The Gulf of Alaska: physical environment and biological resources. US Ocean Assessments Division, Alaska, p 343-395

Görlich K, Weslawski JM, Zajaczkowski M (1987) Suspension settling effect on macrobenthos biomass distribution in the Hornsund fjord, Spitsbergen. Polar Res 5:175-192

Gray JS (1997) Marine biodiversity: patterns, threats and conservation needs. Biodivers Conserv 6:153-175

Grebmeier JM, McRoy CP, Feder HM (1988) Pelagic benthic coupling on the shelf of the northern Bering and Chukchi Seas. I. Food supply source and benthic biomass. Mar Ecol Prog Ser 48:57-67

Grebmeier JM, Feder HM, McRoy CP (1989) Pelagic-benthic coupling on the shelf of the northern Bering and Chukchi Seas. II. Benthic community structure. Mar Ecol Prog Ser 51:253-268

Holte B, Dahle S, Gulliksen B, Naes K (1996) Some macrofaunal effects of local pollution and glacier-induced sedimentation with indicative chemical analyses in the sediments of two Arctic fjords. Polar Biol 16:549-557

Huston M (1979) A general hypothesis of species diversity. Am Nat 113:81-101

Kendall MA (1994) Polychaete assemblages along a depth gradient in a Spitsbergen Fjord. In: Dauvin JC, Laubier L, Reish DJ (eds) Acte de la 4eme Conférence internationale des Polychetes. Mem Mus Nat Hist Nat 162:463-470

Kendall MA, Aschan M (1993) Latitudinal gradients in the structure of macrobenthic communities: a comparison of arctic tropical and temperate sites. J Exp Mar Biol Ecol 172:157-170

Lake PS (1990) Disturbing hard and soft bottom communities: a comparison of marine and freshwater environments. Aust J Ecol 15:477-488

Lambshead PJD, Platt HM, Shaw KM (1983) The detection of differences among assemblages of marine benthic species based on an assessment of dominance and diversity. J Nat Hist 17:859-874
Lefauconnier B, Hagen JO, Rudant JP (1994) Flow speed and calving rate of Kongsbreen glacier, $70^{\circ} \mathrm{N}$ Spitsbergen, Svalbard, using SPOT images. Polar Res 13:59-66

Moore PG (1977) Inorganic particulate suspensions in the sea and their effects on marine animals. Oceanogr Mar Biol Anu Rev 15:225-363

Sanders HL (1968) Marine benthic diversity: a comparative study. Am Nat 102:243-282

Schmid MK, Piepenburg D (1993) The benthos zonation of the Disko Fjord, West Greenland. Medd Gronland Biosci 37: 3-21

Shannon CE, Weaver W (1963) The mathematical theory of communication. University of Illinois Press, Urbana

Smith CR, Kukert H (1996) Macrobenthic community structure, secondary production and rates of bioturbation and sedimentation at the Kane'ohe Bay Lagoon floor. Pac Sci 50:211-229

Subba Rao DV, Platt T (1984) Primary production of arctic waters. Polar Biol 3:191-201

Svendsen JI, Elverhoi A, Mangerud J (1996) The retreat of the Barents Sea ice sheet on the western Svalbard margin. Boreas 25:244-256

Swerpel S (1992) Hydrometeorological conditions in Tikhaia Bay, Franz Josef Land, during summer 1991. In: Gjertz I, Morkved B (eds) Environmental studies from Franz Josef Land with emphasis on Tikhaia Bay, Hooker Island. Norsk Polarinstitutt, Oslo, p 9-13

Syvitski JPM, Andrews JT (1994) Climate change: numerical modelling of sedimentation and coastal processes, eastern Canadian Arctic. Arct Alp Res 26:199-212

Vaughan DG, Doake CSM (1996) Recent atmospheric warming and retreat of ice shelves on the Antarctic Peninsula. Nature 379:328-331

Warwick RM, Ruswahyuni (1987) Comparative study of the structure of some tropical and temperate marine softbottom macrobenthic communities. Mar Biol 95:641-649

Weslawski JM (1993a) The comparison of West Spitsbergen and Franz Josef Land coastal marine ecosystems. Stud Mat Ocean 64:331-341

Weslawski JM (1993b) The sensitivity of Svalbard's marine ecosystem towards climatic change. Institute of Oceanology, Polish Academy of Sciences, Sopot (in Polish)

Weslawski JM, Stempniewicz L (1995) Marine environment and wildlife. In: Barr S (ed) Franz Josef Land. Norsk Polarinstitutt, Oslo, p 38-58

Weslawski JM, Zajaczkowski M (1992) Benthic fauna and its environment in Tikhaia bay, Hooker Island. In: Gjertz I, Morkved B (eds) Environmental studies from Franz Josef Land with emphasis on Tikhaia Bay, Hooker Island. Norsk Polarinstitutt, Oslo, p 35-42

Weslawski JM, Koszteyn J, Zajaczkowski M, Wiktor J, Kwasniewski S (1995) Fresh water in Svalbard fjord ecosystems In: Skjoldal HR, Hopkins C, Erikstad KE, Leinaas HP (eds) Ecology of fjords and coastal Waters. Elsevier, New York, p 229-241

Wiktor J, Zajaczkowski M (1992) Suspended matter and phytoplankton in Tikhaia Bay. Summer 1991. In: Gjertz I, Morkved B (eds) Environmental studies from Franz Josef Land with emphasis on Tikhaia Bay, Hooker Island. Norsk Polarinstitutt, Oslo, p 14-18

Wilber CG (1971) Turbidity. Animals. In: Kinne O (ed.) Marine Ecology. Wiley-Interscience, London, p 1180-1189

Wlodarska M, Weslawski JM, Gromisz S (1996) A comparison of the macrofaunal community structure and diversity in two arctic glacial bays - a 'cold' one off Franz Josef Land and a 'warm' one off Spitsbergen. Oceanologia 38: $251-283$ 